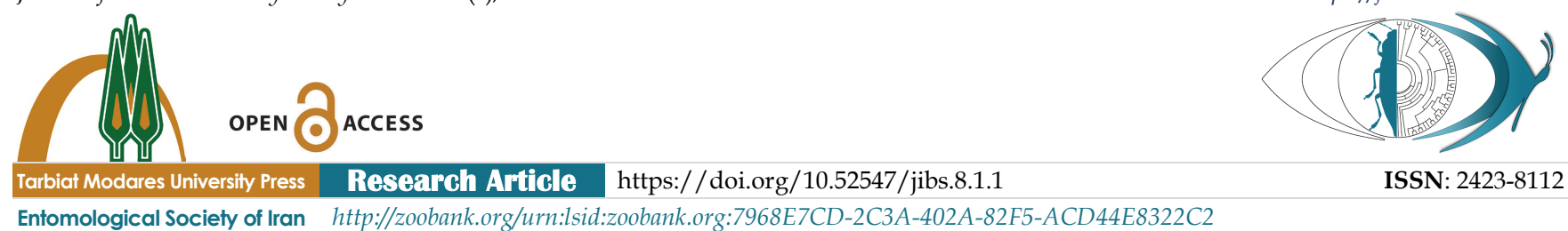

\title{
New and reconfirmed records of Sphenoptera orichalcea (Pallas, 1781) (Coleoptera, Buprestidae) from Iran and Armenia
}

\author{
Mark Kalashian \\ Scientific Center of Zoology and Hydroecology, National Academy of Sciences of Armenia, P. Sevak str., 7, Yerevan, 0014. \\ $\triangle$ mkalashian1@gmail.com; (iD https://orcid.org/0000-0002-2448-9547
}

\author{
Morteza Davodi \\ Department of Plant Protection, Faculty of Agriculture, Urmia University, Urmia, Iran. \\ $\triangle$ mortezadavoodi51@gmail.com; (iD https:// orcid.org/0000-0002-4473-6621
}

\section{Younes Karimpour}

Department of Plant Protection, Faculty of Agriculture, Urmia University, Urmia, Iran. هy.karimpour@urmia.ac.ir; (i) https:// orcid.org/0000-0003-2468-8367

Received:

16 September, 2021

Accepted:

08 November, 2021

Published:

05 January, 2022

Subject Editor:

Sayeh Serri
ABSTRACT. Based on materials recently collected in Iran and Armenia, jewel-beetle Sphenoptera (Chrysoblemma) orichalcea (Pallas, 1781) is reported for the first time for Iranian fauna, and occurrence of the species in Armenia is also reconfirmed. Some diagnostic characters, ecological and biological notes along with photographs are provided.

Key words: Jewel-beetle, new records, Caucasia, Wetlands, Saltlands

Citation: Kalashian, M., Davodi, M. \& Karimpour, Y. (2022) New and reconfirmed records of Sphenoptera orichalcea (Pallas, 1781) (Coleoptera, Buprestidae) from Iran and Armenia. Journal of Insect Biodiversity and Systematics, 8 (1), $001-007$.

\section{INTRODUCTION}

The genus Sphenoptera Dejean, 1833 is a very large and diverse assemblage of beautiful buprestids (Coleoptera, Buprestidae), which include about 1200 species, distributed mainly in the arid and semiarid areas of Southern Palearctic, Ethiopian and Oriental regions (Bellamy, 2008). The larvae of Sphenoptera species develop in the roots and stems of perennial herbaceous plants and semi-shrubs, some species are also living under the bark of trees and shrubs (Krivosheina, 1975; Alexeev, 1981; Zykov, 1995; Jalil \& Ali, 2020). There are many taxonomic problems among species of the genus Sphenoptera. These difficulties are due to lack of enough reliable morphological characters for separating the species and the high level of variabilities arising from the environmental conditions and the host plants (Kalashian \& Sakalian, 2007). Both complicated taxonomy and the large number of synonyms have caused Sphenoptera to be one of the taxa with vast number of inconsistencies in species records (Volkovitsh \& Kalashian 2003; Kalashian et al., 2005a, 2005b; Kalashian \& Volkovitsh, 2009; Volkovitsh \& Kalashian, 2016).

In the annotated catalogue of the Iranian jewel beetles (Coleoptera: Buprestidae) (Ghahari et al., 2015), 111 species of Sphenoptera have been listed, of which 31 species are endemic to the country. Occurrence of 13 species is considered doubtful. For Armenia, 53 species (Five endemic) have been recorded so far (Volkovitsh \& Kalashian, 2016); some records are based on the old data, need

Corresponding author: Karimpour, Y., E-mail: y.karimpour@urmia.ac.ir

Copyright (C) 2022, Karimpour et al. This is an open access article distributed under the terms of the Creative Commons NonCommercial Attribution License (CC BY NC 4.0), which permits Share - copy and redistribute the material in any medium or format, and Adapt - remix, transform, and build upon the material, under the Attribution-NonCommercial terms. 
confirmation. In the course of samplings conducted in Iran (by Y. Karimpour) and Armenia (by M. Kalashian), specimens of Sphenoptera (Chrysoblemma) orichalcea (Pallas, 1781) were found, representing first record for Iranian fauna and re-discovery in Armenia.

\section{MATERIAL AND METHODS}

Sampling surveys were conducted in Iran/West Azarbaijan province during May of 2019-2020 to find the phytophagous insects associated with Halocnemum strobilaceum. In order to find the root-feeding insects, we started to collect the plants with symptoms of infestations on their roots. Samples were picked out from root and crowns of host plants about $10 \mathrm{~cm}$ from the top of the soil. About 50 samples of the roots were collected. The collected materials were brought to the laboratory and placed into the prepared glass boxes $(30 \times 40 \times 80 \mathrm{~cm})$, covered by muslin for maintenance and rearing of insects under laboratory conditions $\left(27 \pm 2{ }^{\circ} \mathrm{C} ; 70 \pm 5 \%\right.$ relative humidity and a photoperiod of $\left.12: 12 \mathrm{~L}: \mathrm{D}\right)$. Boxes were checked daily for emerging insects. In Armenia, the beetle specimens were collected using the standard entomological sweep net. Collected beetles were killed, air dried and mounted for identification. The specimens were identified using the keys of Richter \& Alexeev (1965) and description in Volkovitsh \& Kalashian (2003). All observations and studies related to the life cycle of the beetle were performed in the field. To determine the biological stage of the beetle related to its life cycle, the roots of $H$. strobilaceum were pulled out of the soil at different times and split. Relevant date and immature stages of the beetle inside the roots (Fig. 1) were recorded. The voucher specimens are deposited in the collections of the Natural History Museum of Urmia University (NHMUU) and of the Institute of Zoology, Scientific Center of Zoology and Hydroecology, National Academy of Sciences of Armenia (NASA).

\section{RESULTS}

Taxonomic Accounts

Order: Coleoptera Linnaeus, 1758

Family: Buprestidae Leach, 1815

Genus Sphenoptera Dejean, 1833

Sphenoptera (Chrysoblemma) orichalcea (Pallas, 1781) (Figs 1-3)

Syn.: Sphenoptera fossulata Zoubkoff, 1829:157; Sphenoptera meyeri Gebler, 1830:76; Sphenoptera karelini Faldermann, 1833:46; Sphenoptera cupraria Mannerheim, 1837:96; Sphenoptera australis Gory \& Laporte, 1839:34; Sphenoptera zoubkoffii Gory, 1841:312; Sphenoptera impressicollis Motschulsky, 1860:414; Sphenoptera aciculata Marseul, 1865:395; Sphenoptera solskyi Becker, 1867:108; Sphenoptera cuprea Ballion, 1878; Sphenoptera wilkinsi Jakovlev, 1887:117; Sphenoptera astrachanica Reitter, 1890:278; Sphenoptera pruinosa Abeille de Perrin, 1891:267.

Materials examined: 1ㅅ, 1 우 (NHMUU), IRAN, West Azarbaijan (Azarbaijan-e Gharbi) province, saline lands around Soldoz wetland, 3702'29" N, 4536'53" E, Elev. 1280 m a.s.l., ex Halocnemum strobilaceum

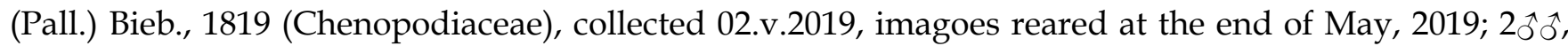
1 우 (NASA), same data, but collected at 07.v.2020, imagoes reared at the end of May, 2020, leg.: Y. Karimpour (Fig. 2B); 10ิ, ARMENIA, Armavir prov., env. Arazap, "Vordan karmir" State Sanctuary,

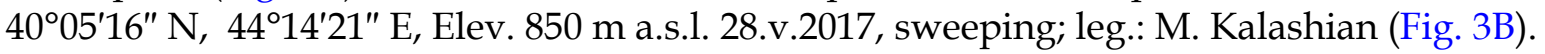

\section{Diagnosis (Fig. 2B - female; Fig. 3B - male)}

Beetles of both sexes are of medium size, body length 7-17 mm, dorsal coloration very variable, from golden-green to blackish-bronzy, dorsal integument microrericulated, with distinct silky luster. Pronotum widest near or before middle with sides subparallel in posterior half and with approximately straight posterior angles, disk flattened medially. Anterior three-fifth of elytra are subparallel, apically elytra with three sharp teeth on each elytron. Sphenoptera orichalcea belongs to the subgenus 
Chrysoblemma Jakovlev, 1889, which is characterized by the same structure of elytral apices. All other species of the subgenus from Iran and Armenia except of S. tristicula Reitter, 1895 have smooth and shiny dorsal integument; pronotum in these species is widest behind middle, with sides more or less divergent towards sharp posterior angles. Sphenoptera tristicula with structure of dorsal integument similar to $S$. orichalcea is black with more or less distinct bluish reflection, pronotum spheroidal with disk nearly regularly convex.

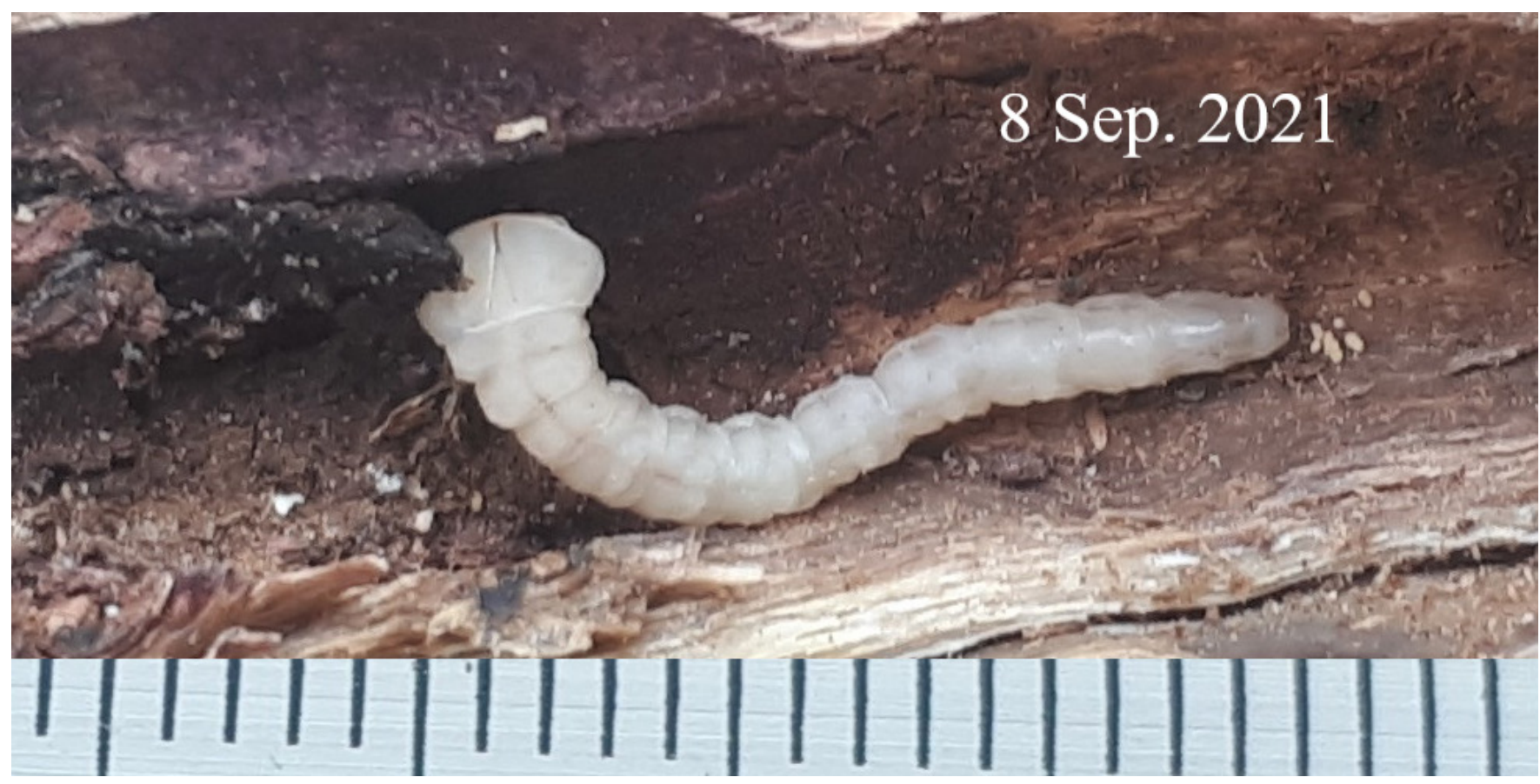

Figure 1. The larva of Sphenoptera orichalcea inside the root of $H$. strobilaceum (saline lands around the Soldoz wetland, West Azarbaijan, Iran).

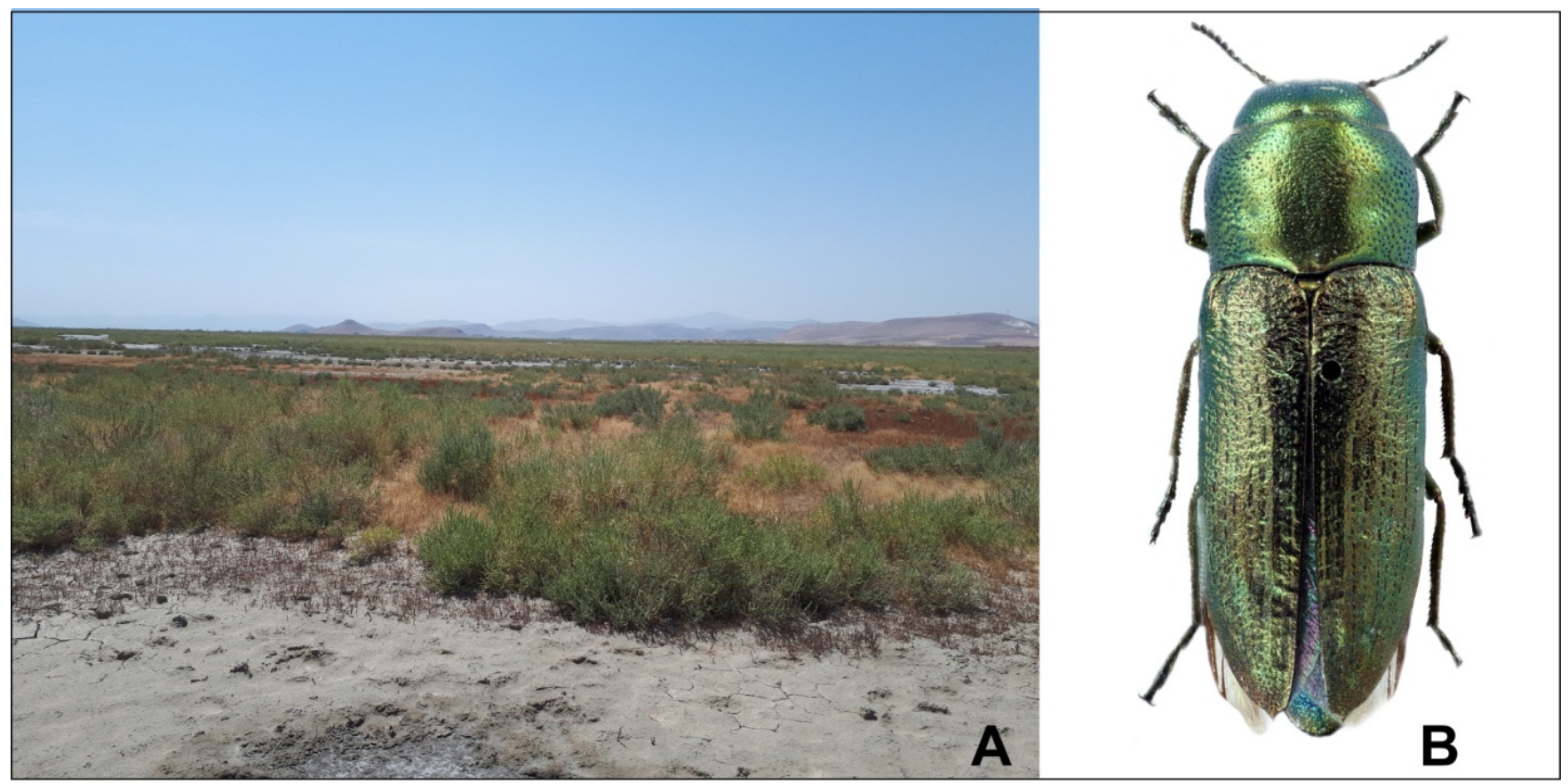

Figure 2. A. Habitat in Soldoz wetland (West Azarbaijan, Iran); B. Sphenoptera orichalcea, female. 


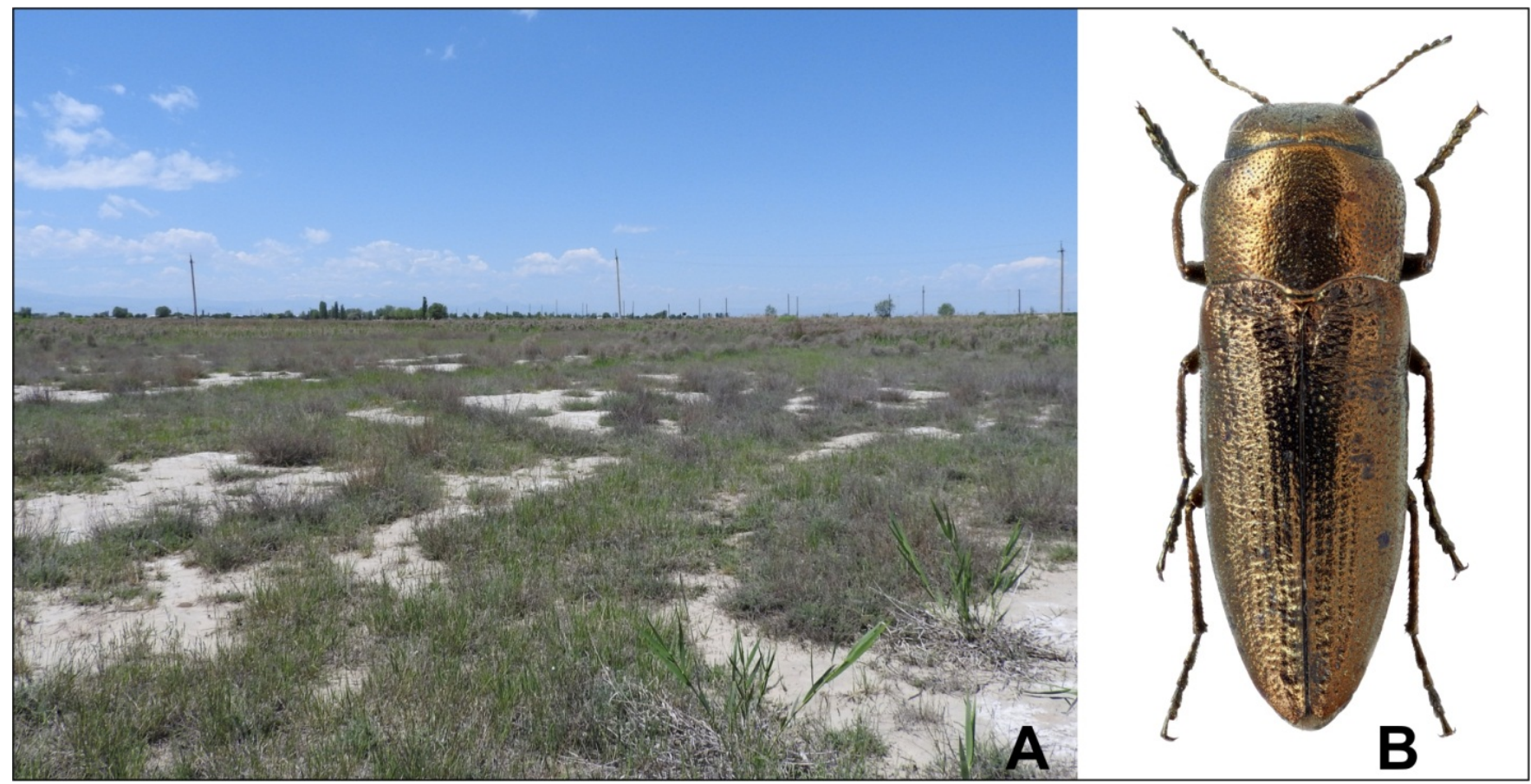

Figure 3. A. Habitat in "Vordan karmir" sanctuary (Armenia); B. Sphenoptera orichalcea, male.

\section{Life cycle}

Adult beetles appear from mid-May. After emergence and mating, the fertile female beetles make an oviposition hole in the upper parts of host plant stem and lay single egg in each hole. After hatching, young larvae tunnel down the $H$. strobilaceum stem until reaching the root area just below the soil surface. The larvae feed on the main and lateral roots of the host plant and make a distinct mine in it (Fig. 1). The beetle complete one generation per year and overwinters as full development larvae.

\section{DISCUSSION}

Sphenoptera orichalcea is a South Palearctic species, distributed in South-East European Russia, SouthWest Siberia, Kazakhstan, countries of Central Asia, Mongolia and Northern China (Volkovitsh \& Kalashian, 2003, 2016). The species has already reported from Dagestan (Reitter, 1895 - as S. astrachanica Reitter, 1890), Caucasus (Reitter et al., 1906 - as S. karelini Faldermann, 1835) and Southern Transcaucasia (Azerbaijan and Armenia) (Volkovitsh \& Kalashian, 2016). Several host plants of different families, including Polygonaceae (Atraphaxis L.), Fabaceae (Caragana F.) and several Amaranthaceae (Bassia All. = Kochia Roth, Anabasis L., Kalidium Moq., Halocnenum M. B.) (Serkova, 1958; Taranov, 1987; Alexeev et al., 1990) are recorded from this species. Depending of diversity of host plants, the beetle represents several ecological forms which lead to description of numerous synonyms species (Volkovitsh \& Kalashian, 2003). In Iran, specimens of S. orichalceae were obtained by rearing from its larvae feeding in the crown and roots of $H$. strobilaceum (Figs 1, 2A, B) which had been collected from the saline lands of Soldoz wetland. In this area, H. strobilaceum is a dominant halophytic species and often forms monodominant communities or co-occurs with Puccinellia distans (Jacq.) Parl. (Poaceae) and Aeluropus sp. (Poaceae). According to EUNIS classification (Davies et al., 2004) the habitat can be classified as Continental inland salt steppes. In Armenia this species was collected in very similar habitat also classified as Continental inland salt steppes (Aeluropus spp. dominated habitats) (Fayvush \& Alexanyan, 2016) (Fig. 3A, B). Host plant remains unknown, but taking into consideration morphological peculiarities of the specimen collected (see Volkovitsh \& Kalashian, 2003) the species most probably is developing also on $H$. strobilaceum which is presented and very common in the abovementioned plant community. 
Sphenoptera orichalcea was originally reported from Armenia only by Morawitz (1877) as S. karelini Faldermann, 1833, collected by himself in 1875 in the environs of Etschmiadzin. On the base of this record the species was reported for Armenia (as "Erivan" [governorate]) in catalogues of Jacobson (1913) and Obenberger (1930) which was accepted in recently published Catalogue of Palaearctic Coleoptera (Volkovitsh \& Kalashian, 2016) though the latter authors could not find any specimen of $S$. orichalcea from Armenia in several European collections. Thus, no specimen was reliably found in Armenia during more than 1.5 century, and the above-mentioned specimen is new evidence confirming presence of $S$. orichalcea in Armenian fauna.

\section{AUTHOR'S CONTRIBUTION}

MK: Collected and sorted the specimens and recorded the biological data in Armenia, compared the specimens with type material. MD: Specimens collection and record the biological data in Iran. YK: Collection and storage of the specimens along with record of biological data in Iran, preparation of the draft. All authors read and approved the final contents of the manuscript.

\section{FUNDING}

This article is part of the second author's dissertation number 4088 in the Department of Plant Protection, Faculty of Agriculture, Urmia University.

\section{AVAILABILITY OF DATA AND MATERIAL}

Not applicable.

\section{ETHICS APPROVAL AND CONSENT TO PARTICIPATE}

Not applicable.

\section{CONSENT FOR PUBLICATION}

Not applicable.

\section{CONFLICT OF INTERESTS}

The authors declare that there is no conflict of interest regarding the publication of this paper.

\section{ACKNOWLEDGMENTS}

Authors are very grateful to Dr. Gayane Karagyan and Tigran Ghrejyan (both from Scientific Center of Zoology and Hydroecology NAS RA, Yerevan, Armenia) for providing photographs of habitat in Armenia and of specimens of $S$. orichalcea, respectively. Special thanks to the staff of Reserve and Parks complex SNCE, Ministry of Environment of RA (Jrvezh, Armenia) who supported the expedition work of M. Kalashian in "Vordan karmir" sanctuary. The work in Armenia was partly supported by the RA Science Committee and Russian Foundation for Basic Research (RF) in the frames of the joint research project SCS 20RF-089 and RFBR 20-54-05004, accordingly."

\section{REFERENCES}

Alekseev, A.V. (1981) Materials on the morphology and taxonomy of the larvae of jewel-beetles genus Sphenoptera Sol. (Coleoptera, Buprestidae). Voprosy obstschei entomologii, 63, 76-78. [In Russian]

Alekseev, A.V., Zykov, I.E. \& Soyunov, O.S. (1990) New material on the larvae of Sphenoptera Sol. (Coleoptera, Buprestidae) from the deserts of Transcaucasia, Kazakhstan and Central Asia. Trudy Akademii Nauk Turkmenskoi SSR. Seriya Biologicheskih Nauk, 3, 30-38. [In Russian]

Bellamy, C.L. (2008) A World Catalogue and Bibliography of the Jewel Beetles (Coleoptera: Buprestidae), Vol. 3 Buprestinae: Pterobothrini through Agrilinae: Rhaeboscelina. Pensoft Series Faunistica no. 78, Pensoft, Sofia, pp. 1261-1931.

Davies, C.E., Moss, D. \& Hill, M.O. (2004) EUNIS Habitat Classification Revised. European Environment Agency, European Topic Centre on Nature Protection and Biodiversity. 310 pp. 
Fayvush, G.M. \& Aleksanyan, A.S. (2016) Habitats of Armenia. NAS RA, Institute of Botany, Yerevan. 360 pp. [in Russian with partly parallel English text]

Ghahari, H., Volkovitsh, M.G. \& Bellamy, C.L. (2015) An annotated catalogue of the Buprestidae of Iran (Coleoptera: Buprestoidea). Zootaxa, 3984, 1-141. https://doi.org/10.11646/zootaxa.3984.1.1

Jacobson, G.G. (1913) Zhuki Rossii I Zapadnoy Evropy. A.F. Devrien, St. Petersburg, 10, 770-800.

Kalashian, M. \& Sakalian, V.P. (2007) A review of the genus Sphenoptera Dejean, 1833 (Coleoptera: Buprestidae) of the Balkan peninsula. Acta Zoologica Bulgarica, 59 (1), 17-28. https:// doi.org/10.23885/1814-3326-2007-3-1-35-40

Kalashian, M.Y., Volkovitsh, M.G. \& Niehuis, M. (2005a) Taxonomic notes on some Palaearctic species of Sphenoptera from subgenus Chilostetha (Coleoptera: Buprestidae). Zoosystematica Rossica, 14 (1), 77-86. https://doi.org/10.31610/zsr/2005.14.1.87

Kalashian, M.Y., Volkovitsh, M.G. \& Niehuis, M. (2005b) Taxonomic notes on some Palaearctic species of Sphenoptera from subgenera Deudora and Sphenoptera s.str. (part) (Coleoptera: Buprestidae). Zoosystematica Rossica, 14 (1), 87-100. https://doi.org/10.31610/zsr/2005.14.1.87

Kalashian, M.Y. \& Volkovitsh, M.G. (2009) New species of the buprestid genus Sphenoptera Dejean from India and Pakistan with notes on the synonymy and nomenclature of some species of the subgenus Sphenoptera s. str. (Coleoptera, Buprestidae). Entomological Review, 89 (4), 437-450. https://doi.org/10.1134/S0013873809040083

Krivosheina, N.P. (1975). Biology of rhizobiont insects of desert plants. In: Mamaev, B.M. \& Pravdin, F.N. (eds) Insects as Components of the Biogeocenosis of the Saxaul Forest. Nauka publishers, Moscow, pp. 127-158. [in Russian]

Jalil, P.A. \& Ali, W.K. (2020) Addenda to the knowledge of buprestidae fauna in Erbil province, Kurdistan regionIraq. Pakistan Entomologist, 42 (1), 1-10. https:/ / doi.org/10.13140/RG.2.2.30528.97282

Morawitz, F. (1877) Notice sur l'excursion entomologique dans le Caucase. Horae Societatis Entomologicae Rossica, 12, 7-10.

Obenberger, J. (1930) Buprestidae II. In: Junk, W. \& Schenkling, S. (eds) Coleopterorum Catalogus. W. Junk, Berlin, pp. 213-568.

Reitter, E. (1895) Uebersicht der trispinosen Sphenoptera-Arten (Oplistura und Chrysoblemma) aus der palaearctischen Fauna. Wiener Entomologische Zeitung, 14, 32-42.

Reitter, E. von Heyden, L. \& Weise J. (1906) Catalogus Coleopterorum Europae, Caucasi et Armeniae Rossicae. Friedländer \& Sohn, Edmund Reitter, Paskau, Revue d'Entomologie, Caen, Berlin. 774 pp. https://doi.org/10.5962/bhl.title.8788

Richter, A.A. \& Alexeev, A.V. (1965) Buprestidae - Jewel-beetles. In: Gurjeva, E.L. \& Kryzhanovskij, O.N. (eds) Guide to Identification of Insects of the European Part of the USSR, Vol. 2, Nauka Publishers, Moscow, pp. 283-303. [in Russian]

Serkova, L.G. (1958) Insects, pests of the herbs in Betpak Dalinski pastures. Trudy Kazakhskogo NauchnoIssledovatelskogo Instituta Zashchity Rastenii. Almaty, 4, 104-128. [In Russian]

Taranov, B.T. (1987) Principal ecological groups of insect pests of Kochia, with their impact on the productivity of forage Kochia pastures and justification of control measures in the desert area of South-East of Kazakhstan. In: Combating Insects - Pests of Forage Crops and Pasture Plants. Alma-Ata, pp. 59-72. [In Russian]

Volkovitsh, M.G. \& Kalashian M.Y. (2003) A new species of Sphenoptera (subgenus Chrysoblemma) from Iran with taxonomic notes on some Palaearctic species of Sphenoptera from subgenera Chrysoblemma, Hoplistura and Tropeopeltis (Coleoptera: Buprestidae). Zoosystematica Rossica, 11 (2), 331-342.

Volkovitsh, M.G. \& Kalashian M.J. (2016) Buprestidae: Chrysochroinae: Sphenopterini. In: Löbl, I. \& Löbl, D. (eds) Catalogue of Palearctic Coleoptera, Updated and revised edition. Vol. 3, Scarabaeoidea, Scirtoidea, Dascilloidea, Buprestoidea, Byrroidea. Brill/Leyden, Boston, pp. 352-369.

Zykov, I.E. (1995) Jewel-beetles of the genus Sphenoptera (Coleoptera, Buprestidae) - pests of fruit stone crops of Transcaucasia and middle Asia. Zoologicheskii Zhurnal, 74, 41-56. [in Russian] 
اولين و تاييد كزارش (Coleoptera, Buprestidae) Sphenoptera (Chrysoblemma) orichalcea (Pallas, 1781) از ايران و ارمنستان

مارك كالاشيان'، مر تضى داوودى ' و يونس كريميور r."

$$
\begin{aligned}
& 1 \text { ا مركز مطالعات علمى جانورشناسى و اكولوزى آب، آكادمى علوم ارمنستان. }
\end{aligned}
$$

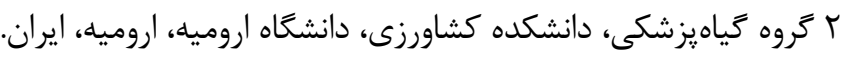

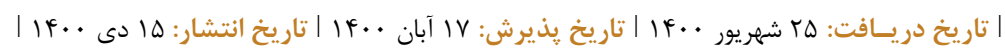

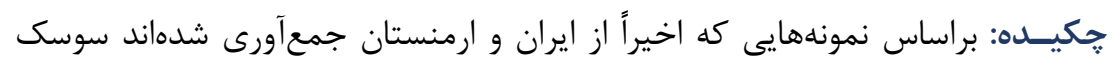

Sphenoptera (Chrysoblemma) orichalcea (Pallas, 1781)

كزارش و انتشار آن در ارمنستان نيز تاييد شد. برخى از ويزَّىهاى تشخيص كونه،

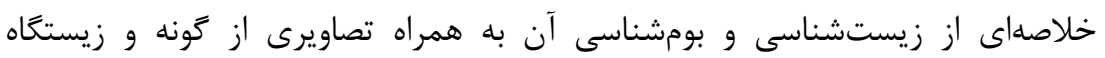

مربوطه ارايه شد.

وازَّــان كليدى: سوسك جواهر، كزارشهاى جديد، قفقاز، تالابها، نمكزارها 